\title{
BANDIT: HERE TO HAUNT YOU! ON WHY I BECAME AN ÉMIGRÉ THEATRE MAKER
}

Summary. The article employs concepts of time lag, inspired by Ernst Bloch, and ghost and haunting, borrowed from Jacques Derrida. It also draws on Svetlana Boym's and Vilém Flusser's vision of the émigré and on Dominick LaCapra's and Slavoj Žižek's interpretations of trauma. The analysis is also informed by Karen Jürs-Munby's and Cathy Caruth's views on trauma and its representation in theatre.

This critical apparatus is put into motion in the particular context of BANDIT: a theatre project developed in the UK by two Romanian émigré theatre-makers. The main focus is on exposing links between the references to trauma contained in the theatre piece BANDIT and the makers' self-imposed artistic exile in the UK. The article seeks to answer the following question: what has pushed us, the makers of BANDIT, to leave our native country and what is our (new) role (as artists) in the country of emigration? The discussion is carried out within the wider context of the vast waves of Romanian emigration to Western Europe (after the fall of the Iron Curtain). The article critiques the troublesome relation of the contemporary Romanian society to its Communist past and the apparent inability and/or unwillingness to deal with the repressed/traumatic memories of that past. Analysis of BANDIT as performance of lingering trauma also references the historical Percentages agreement between Stalin and Churchill-the informal agreement that established spheres of influence in Europe at the end of the Second World War. Identifying the Iron Curtain as the epicentre of traumatic memory for Eastern Europeans, the discussion about BANDIT also makes a reference to Communist crimes against political prisoners committed in Romanian prisons in 1951-1952, put in parallel with the toxic EU referendum campaign in the UK in 2016. Underpinned by Derrida's thinking, the article explains how the Romanian émigré-artist (as a paragon of the Romanian / Eastern European émigré in general) has to fashion herself into a ghost that haunts the adoptive culture, using artistic exile as a platform for processing the traumatic memories of an unresolved past.

Keywords: time lag, émigré, trauma, Communism, ghost, haunting, Churchill.

\section{TIME LAG AND BECOMING A GHOST}

Up to the star that's just appeared

The journey's long, and so

For thousand years its light's careered

To reach us here, below.

It may have faded on its way

Of old, in blue spheres bright

Though only now its shining ray

Unfolds to this our sight.

The image of the star that died

Comes slowly to the fore;

It used to be when it would hide -

We see what is no more.
And likewise, while our yearning dove

Died in the deepest night

The light of the extinguished love

Still follows us in flight. ${ }^{1}$

This is one of the few good versions of La Steaua (To the Star): a poem published for the first time in 1886 and translated into English by Andrei Bantaş later in the 20th century. In the stanzas quoted above, Mihai Eminescu—arguably Romania's most revered poet-describes the phenomenon of time lag. Mastering the suggestive powers of metaphor, Eminescu illustrates how the image of a rising star reaches us on Earth only belatedly: in its ghostly light-form, the now-dead star has traveled through the Cosmos 
to reach - thousands of years later-the bewildered eyes of an onlooker from the future. The ghost of the dead star-a metaphor of love or trauma consumed a long time ago-haunts the spectators from "thousands of years" in the future.

In his influential essay The Heritage of Our Times, Marxist philosopher Ernst Bloch also refers to time lag-this time in perhaps less poetic a mannercautioning that "times older than the present" may come back from the past to haunt us. ${ }^{2}$ Bloch exposes the uneven temporal development (time lag) across inter-war Germany and suggests that popularity of National Socialism (in the period preceding the Second World War) could also be understood as the ghostly return of "an uncompleted past which has not yet been 'sublated' by capitalism['s]" modernisation to Germany. ${ }^{3}$ Having informed, throughout the 20th century, the thinking of various Marxist philosophers (like Theodor Adorno and Louis Althusser), theories of modernity and postmodernity (Fredric Jameson), and post-colonial theory (Homi Bhabha), Bloch's idea of time lag appears particularly relevant to the question posed in this article. I combine Bloch's pragmatic stance with Eminescu's poetic stance and obtain a key proposition: according to Eminescu, our present is always a product of time lag (it always contains the specter/s of something that died before reaching us). In certain conditions, these specters are dark and their existence in the present is toxic and negative. Having made this proposition, I return to the initial question posed in this article and attempt the first possible response: is it not possible that a kind of negative time lag could have pushed us, the makers of BANDIT, to leave our native country? And if so, does not our role as émigré artists also involve some form of haunting? To remain in line with the spirit of these preliminary answers, the BANDIT theatre project will have to be considered primarily as an investigative tool. Therefore, the assumption is that the makers have used the BANDIT performance as a means to reflect on and understand (as much as possible) how a time lag might have compelled them to leave their home country (Romania) and emigrate to the UK. Furthermore, the makers of BANDIT have used the performance piece as a means to define/understand their roles/function as artists who are haunting the country of their emigration.

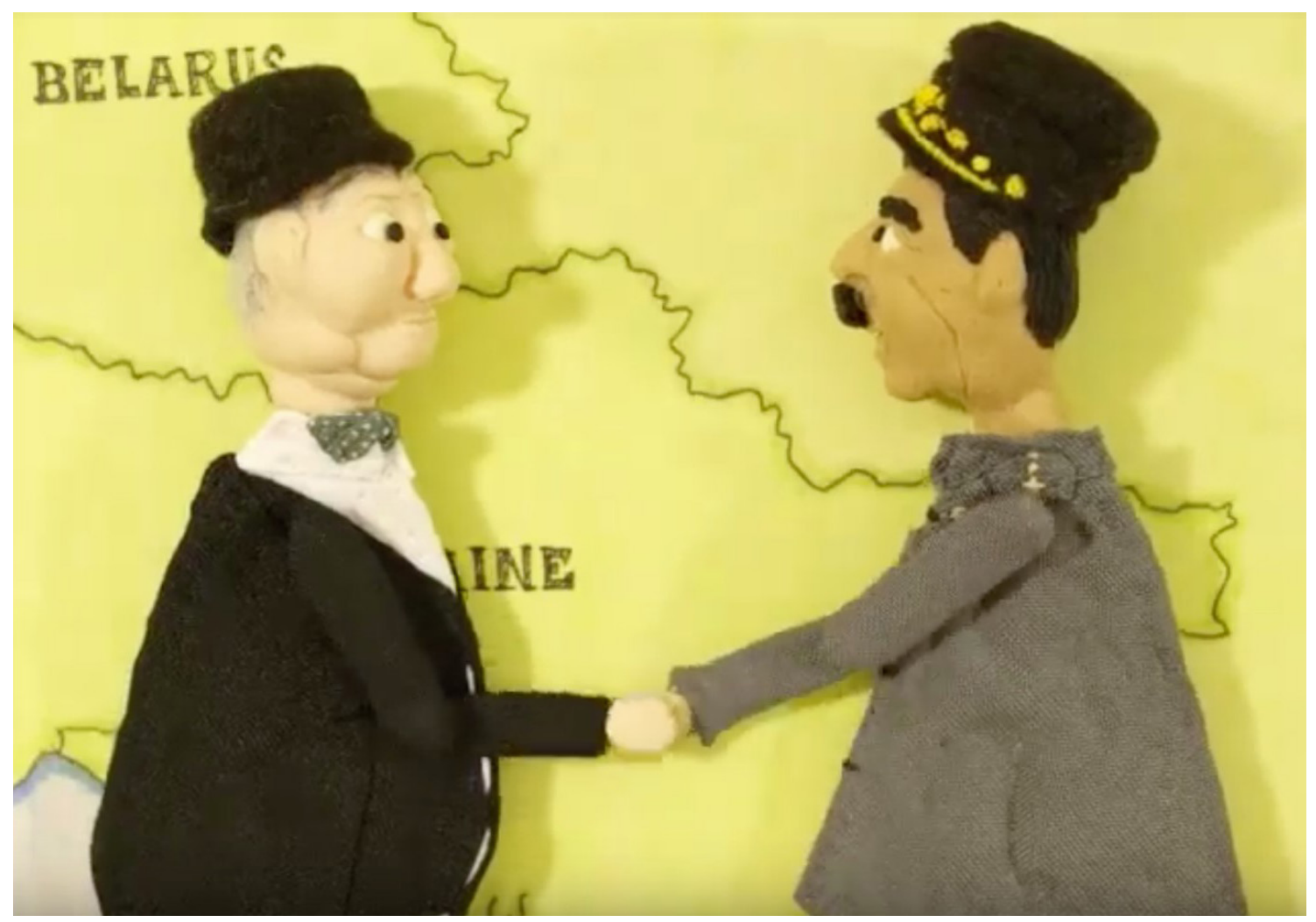

Fig. 1. Still from the short film in the opening of BANDIT. Animation by Hannah Taggart. Copyright Nu Nu Theatre 
In the light of the above considerations, it is significant to note that BANDIT begins with an animated film focused on the descent of the Iron Curtain across Europe. In the short film, animated characters of Stalin and Churchill are seen presiding over the post-war partition of Europe. Arguably, the emergence of the Iron Curtain constituted the most brutal rupture experienced by Romania (and Eastern Europe as a whole) in recent history and marked the beginning of an evident time lag between the East and the West of Europe. Justifiably so, symbolism of the Iron Curtain is featured in the overture of the theatre piece BANDIT, signifying the epicentre of the time lag in Eastern Europe and the cornerstone to the artists' understanding of their emigration from Romania some sixty years later. The brutal nature of the Iron Curtain, which has enabled an artificial time lag to cut through the middle of Europe between 1945 and 1989, is aptly encapsulated by poet Ana Blandiana's description: "That particular line where the map of Europe has many times been folded and almost torn." Almost completely torn in 1945, the brutally-folded map of Europe pushed Romania into an induced time lag: a paradoxical reality in which half of Europe, bound as it was by centuries-old cultural, economic, and political ties to the other half, was being forced to exist on a totally different temporal plane. The deeply traumatic reality of the erection of the Iron Curtain was encapsulated in a colourful, cartoonish animated film and laid at the very foundation of the BANDIT piece as a powerful symbol. Put at the beginning of the performance, this naïve and benign representation of the Iron Curtain tragedy suggests how the imposed time lag became a new reality for Romanian and Eastern European people after 1945. The short film contrasts its deliberate cartoonishness with the darkness, terror, and violence that ensue during the performance of BANDIT. I return to the question of why we, the artists, felt compelled to leave sixty years after the dividing of Europe. It is also very important to consider the historic events of 1989: the Romanian Revolution and the fall of Communism and the Iron Curtain across Europe. These extraordinary events raised hopes-for Romanians, at least—that the curse of over fifty years of time lag would finally be lifted and that the traumatic episode will somehow be healed. It would soon become evident that, whilst the black star of Communism had indeed succumbed, its spectre (as Eminescu poetically suggested) still pervaded the Romanian society, manifesting itself with renewed vigour in the newly-arrived post-Communist era. Paradoxically, the time lag continued to torment Romania (this time by reinventing itself) on a different plane and managed to remain a principal characteristic of the Romanian society, caught in what David Durst called "the painful process of transition". ${ }^{5}$ One of the few certitudes during this painful transition period was the Romanian society's striking inability or unwillingness to deal with the traumas of the past. Immediately after the fall of Communism, Romanian authorities (deliberately?) ignored the need and the call for recuperation of and reconciliation with the traumatic past in the shadow of the Iron Curtain. "The elimination of the seeds of the crimes committed" in that traumatic past-as Bloch was once calling for in Germany-was being postponed. ${ }^{6}$

In that respect, it should be telling that a formal condemnation of the Communist regime was formally read in the Romanian Parliament (in an atmosphere of intense protests and controversy) only in December 2006, marking a delay of seventeen years since the fall of the Iron Curtain and the Communist regime. The archives of the defunct Securitate (the secret services of Communist Romania) were also only very gradually being made available for study under the coordination of the National Council for the Study of Securitate Archives (CNSAS). The particularly slow process started in earnest only in 1999, ten years after the fall of the Communist regime, with the CNSAS initially functioning in a temporary headquarters. A full transfer of the entire archive to the CNSAS (which by now had acquired a building of its own) was granted only in 2003. The opening of the Archive of Military Tribunals (which hosted around 150,000 files with details of political cases against Romanian citizens between 1945 and 1989) was decided by a Government Decree in 1990. By 2006, it was still unclear when the vast archive would be made available to specialists for 
research. In his Existenta prin cultura. Represiune, colaborationism si rezistenta intelectuala sub regimul communist (Existence through Culture. Repression, Collaborationism and Resistance under the Communist Regime), Gabriel Andreescu notes that "the most sensitive and therefore most relevant documents were not made available to the public. The explanation is the continuity of the [Communist] secret services." For a long time, Andreescu says, a situation persisted where "the CNSAS is the manager of the Securitate Archive and the Romanian Intelligence Service (SRI) is its custodian."

Statistics regarding the true number of victims of Communist repression in prisons, labour camps, and psychiatric institutions were very slow to appear in the post-Communist years. Following arduous research, the Institute for the Investigation of Communist Crimes in Romania (IICCR) was rather belatedly able to provide much needed information and statistics from Communist prisons of the second half of the 20th century:

during Communism, 44 main prisons and 72 forced labour camps were functioning in Romania with over 3 million prisoners, 800,000 of whom died. Other statistics give one million as the total number of prisoners. ${ }^{9}$

These examples underline the fact that Romania never recuperated from the time lag created once the Iron Curtain descended across Europe (through legal, moral, and institutional reconciliation with the past). Quite the contrary, the time lag was apparently allowed to reinvent itself, gain a new direction and a new impetus. It must therefore have been this sense of a resurrected, reinvented, haunting time lag which pushed us-the makers of BANDIT-to finally leave our country despite its claims of being a democracy and its recent acceptance to the EU. To us, it became evident that the recuperation of the past with its huge quantities of unprocessed trauma was not going to happen anytime soon in Romania and the effects could be disastrous, as Romanian historian Bujor Nedelcovici pointed out:

A penal or moral delict is a latent evil which poisons the fate of future generations (at least three) and maintains a feeling of unhappiness, a hidden conflict, an ambiguity in behaviour, a lack of resolve in decisive moments, and a tendency towards lies, corruption, and revenge. ${ }^{10}$

Paradoxically, it appeared that emigration-somewhere far away from Romania-would precipitate the recuperation of and reconciliation with our past (a painfully slow and particularly volatile process in our own country) and would allow us to overcome the time lag that we had grown into.

At this junction point in the argument, I will draw on the concepts of ghost and haunting as explicated by philosopher Jacques Derrida mainly in his work Specters of Marx: The State of the Debt, the Work of Mourning and the New International. Derrida links the concept of ghost to wider symptomatology of unprocessed trauma, read in its relation to the passing of time. Therefore, as John Weinstock underlined in Spectral America: Phantoms and the National Imagination, the ghost could be envisaged as something akin to "a symptom of repressed knowledge [...] call[ing] into question the possibilities of a future based on avoidance of the past." ${ }^{\text {11 }}$ The ghost is a conceptual equivalent of an unresolved impetus, of a mysterious energy that questions and challenges the architecture of the present by always referencing a traumatic past. The ghost is a conceptual symptom and materialisation of the torment that the image of a black star stokes upon the present. Slavoj Žižek also uses the concept of symptom to describe "a return of the repressed", a mysterious, ghostly visitation of the present by the unsolved spectres of the past. ${ }^{12}$ Through their emigration (seen as an attempt to understand and control the time lag), the makers of BANDIT partially become messengers and performers of such ghostly, repressed past: they partially become the embodiments of the ghost.

Becoming ghost appeared as one possible solution for liberating the repressed knowledge about the past and for being able to construct a free future as artists and theatre-makers. "The future belongs to ghosts," said Derrida, and the makers of BANDIT take it literally. ${ }^{13}$ The permanence of the time 
lag and its inherent ghostly nature constitute the energy that animates and drives the émigré in his/ her travels and movements; that energy constitutes-to paraphrase Žižek - the real of the émigré: spectral in its essence and "an inert stain resisting communication and interpretation." ${ }^{4}$ The real of all these people pouring into the West is the ghost of a traumatic past. The emigrants become immanent performers of this traumatic instinct to haunt: their ugly-ed faces, their innate otherness, their menacing, ghostly selves are embodiments, signs, miniperformances of an unresolved past and time lag. To put it simply, reality is never directly "itself";

it presents itself only via its incomplete-failed symbolization, and spectral apparitions emerge in this very gap that forever separates reality from the real [...] the spectral gives body to that which escapes (the symbolically structured) reality. [...] What the spectral conceals is not reality but its "primordially repressed", the irrepresentable $\mathrm{X}$ on whose "repression" reality itself is founded. ${ }^{15}$

Following suit, the makers of BANDIT saw themselves compelled to become ghost-artists: émigré artists whose role is to take the haunting and torment, inscribed in a time lag, further into faraway lands of exile, hoping to finally be able to master it.

Romanian historian Lucian Boia observed in The Scientific Mythology of Communism that the Communist ideal was "to conquer freedom, to exit history, and to establish the perfect Communist society." 16 Whilst this ideal might have failed, its ghost seems to have emerged with renewed vigour after the fall of Communism. Fifty years of experimentation with the exit from history and living in an artificially imposed time lag were replaced with a renewed sense of temporal unevenness: the principal characteristic of it being, this time, a deep sense of disillusionment and the sheer impossibility of absorbing the traumatic memories of the past. Now in the third decade of transition towards a very vaguely defined future, the Romanian society remains under a painful impression that it needs to catch up with its own past. Not having the resolve to see how an (elusive and very slow) unearthing of unprocessed trauma might conclude, approximately 3.4 million Romanians (according to the 2017 UN Report) decided to become ghosts and leave their native country between 2007 and $2015 .{ }^{17}$ Most of these spectral people have emigrated because of what might be deemed-in a very pragmatic analysis-as immediate economic reasons, which Bloch would call Romania's un-sublated-ness to capitalism in comparison to richer European countries. It is my view that feelings of unhappiness, hidden conflict, and corruption, named by Nedelcovici, prevailed and pushed so many people to become ghosts and emigrate from their native country. The sheer dimensions of post-Communist emigration from Romania (unusual for a country which is not involved in an armed conflict) speaks volumes about the tragic "consequences of silence" and the great toll that the "inconsistencies of individual and collective memories and their various suppressions" can take on a population. ${ }^{18}$ Millions were leaving a country seemingly unable and/or unwilling to close the story of trauma that had as its epicentre the erection of the Iron Curtain. Maddened by a time lag which never closes, the émigrés have taken to the road in a desperate attempt to master the past that haunts them. Infested by it, they have themselves partially become ghosts and carry this burden in their travels.

\section{HERE TO HAUNT YOU}

In Trauma: Explorations in Memory, Cathy Caruth argues that "the [traumatic] event is not assimilated or experienced fully at the time, but only belatedly, in its repeated possession of the one who experiences it." ${ }^{19}$ This marks a significant critical shift-as Karen Jürs-Munby argues in her article “'Did you mean post-traumatic theatre?': The vicissitudes of traumatic memory in contemporary postdramatic performance"-towards "considering traumatic memory as a trans-individual and collective phenomenon." ${ }^{20}$ As such, the making of BANDIT by two émigré Romanian artists inscribes itself as a luminous and prominent node on a much wider map of trans-individual, collective trauma which moves in tune across Europe and beyond, carried forth by millions of Romanian émigrés. The role 
of the BANDIT project lies therefore in signalling, like a torch in the dark, the massive flow of ghostly darkness moving across the continent from the East to the West. BANDIT is a signal in the midst of an ocean and nothing more.

In her detailed analysis of the relationship between the post-dramatic and the post-traumatic in theatre, titled Memory-Theater and Postmodern Drama, Jeanette Malkin observes how trauma remains hard to capture by narrative/theatrical constructions. She argues, quoting Saul Friedländer, that

narrative forms of memory are integrative by nature; they tend to "restore or establish coherence, closure, and a redemptive state" whilst affirming that the real memory of trauma, so-called deep memory, is, however, resistant to such rational order and unaffected by it. Unmediated and inexpressible, trauma remains unrepresented by narrative constructions. ${ }^{21}$

Malkin doubts the possibility that traumatic experiences can be closed or healed via a cathartic narrative: therefore, a recuperation of the past through the order and coherence specific to theatrical performance is seen as impossible. Applied to the context of BANDIT, this means that the makers cannot expect their project to heal or bring some kind of closure either to the traumatic past or to the time lag itself. What the theatre piece aims to do instead is to expose and process elements of the repressed past, so as to "develop a feeling of mastering the situation that failed to [be mastered] during the traumatic event." ${ }^{22}$ In the theatre project, the ghost-artists engage in what Dominick LaCapra calls (borrowing from Freud) a working-through process: "a selfcritical process bound up with critical thought and practice having social and political import." ${ }^{23}$ With the possibility of catharsis and closure inexistent, emigration and making theatre as an émigré do not solve the time lag nor settle the traumatic memory: emigration only activates the ghostly energies. In other words, the artists' role is to act upon the energy of the ghostly narrative that sent them away from their country in the first place: a recurrent narrative in which trauma remains a living, moving, and evolving trans-individual matter which always flows but does not die. The duty of the makers of BANDIT is therefore to work through-ad infinitum and every time anew-the ocean of traumatic memory, filling the foreign shores of exile with it. Romania's accession to the EU can therefore be seen (beyond the idea of integration into an economic and political bloc) as integration into a much wider circuit for the spreading of traumatic memory. In a symbolic reversal of the Iron Curtain folding of the map, the communicating vessels of the entire Western Europe are now fully open for spectral Easterners to come and work through - in emigration-their traumatic memories and the time lag. Enlargement of the EU therefore functions also as a symbolic (and possibly involuntary) embracing - by the West-of the dark, ghostly, traumatic East. I argue that Eastern Europeans are, indeed, bringing into the EU something more than their ambition to succeed, work ethic, or intellectual and artistic resources. Millions of Romanians are not only bringing their dreams of prosperity and their much-praised hard-working attitude to the West: they are also bringing their unresolved past with them. They bring along, to their long lost West European family, a ghostly dowry of traumatic memory and prolonged experience of time lag. We are talking here about a peculiar, ugly kind of patrimony, which Romanian poet and anti-Communist dissident Ana Blandiana has often praised in her interventions:

[Western] Europe needs us, too, even if presently they do not fully realise that... We, the Easterners, with our suffering, have preserved certain human authenticity which, through integration, we bring as a dowry to the common European patrimony. Because suffering is a patrimony which, throughout the ages, has always been able to generate culture. ${ }^{24}$

Having spent their early years in a Romania where the Communist utopian dream of living outside history was in active disintegration, two artists of $\mathrm{Nu}$ $\mathrm{Nu}$ Theatre (the company that produced BANDIT) joined a long convoy of millions of Romaniansghosts looking for new horizons where to carry their dowry of traumatic memory that just will not 
go away. In 2016, in homage to all these travelling ghosts, the two theatre-makers devised and performed the theatre project BANDIT in Bristol, UK.

BANDIT is a text inspired by one of its makers' encounter (while filming a documentary for the Romanian National Television) with a survivor of the Pitești Experiment, one of the most terrible acts of barbarism of the 20th century. It is important to note that the meeting with a survivor of traumatic past sustains the idea that trauma functions transindividually and echoes throughout times and generations. It was some ten years after that encounter that the BANDIT project was finally completed. During that period, we had been carrying the burden of the Pitești survivor with us as a testimony that traumatic memories are passed on and contagious in their nature. Part of a countrywide campaign to eliminate the Communist regime's adversaries, the Pitești Experiment can be highlighted as the most shocking and brutal exercise of reeducation through torture. It aimed to create the new human, apt and ready to ensure the full implementation of the Communist regime in Romania.

In 1951-1952 in the Pitești (a medium-sized city in Southern Romania) Prison, the authorities were experimenting with reeducation of political prisoners through torture. Constantly beaten and forced to eat their own feces and drink their own urine, torture each other, and testify against their friends, relatives, and colleagues still outside, the prisoners at Pitești were subjected to a continuous programme of violence, interrogation, and humiliation, designed to eventually produce the new type of human. This was to be a model citizen who had left behind all their previous political, moral, ethical, and religious convictions and fully and religiously adhered to the Communist ideals.

In Pitești, the torturers tried their best to reeducate the political prisoners to whom they assigned the generic name of bandits. BANDIT was a term that referred to those who would not voluntarily proclaim the triumphalist vision of society dreamed up by the Communist regime. Being a BANDIT automatically implied being an enemy of the state and social order: as such, BANDITS had to be radically reformed within the widespread imprisonment regime of those years, in which the Pitești Prison was a true human meat mincer. Former political, cultural, and artistic elites, students, wealthier peasants, peasants opposing collectivisation of their land, and generally all who spoke against the Communist regime were pushed into the enormous prison machine.

BANDIT is a theatre piece based on testimonies of the survivors of the Pitești Experiment. The piece is one long monologue that appears as a sum of collaged episodes of torture, crudely and directly translated from Romanian with minimal editing and reconstructed from within the immediate biographical contexts of the tellers. Fragments of horror and trauma are then rearranged into a surreal flow of events that a generic character named BANDIT has to go through. On one indefinite day (a day) of one indefinite December (a December), a student BANDIT is arrested together with his best friend, snatched by the police in the middle of a stroll, imprisoned, starved, and tortured, his friend and inmate brutally killed; more torture follows, and BANDIT is finally pushed to the verge of suicide by his torturers. Although we do not really know if, by the end, BANDIT's suicide attempt succeeds, it becomes clear that, after incessant beatings and gruesome interrogations, the character is left hanging somewhere between life and death. This ending choice echoes the limbo state in which the Romanian society has been enmeshed ever since the fall of the Iron Curtain: caught in a carousel of horrors and unable, after so many years, to approach that past and work through it.

Collaging disparate voices of the survivors as a technique for constructing theatrical discourse allowed the makers of the project to blur the true identity of the torture victims: the tortured-gathered under the generic name of BANDIT-go under the radar and their trauma is depersonalised and dissipated into psychological catacombs of the protagonist. The array of multi-perspectival testimonies pertaining to various lives and personal experiences of torture, reunited in this multi-angular and collaged thread, allow individualities of the survivors to recede, depersonalising and deindividualising 


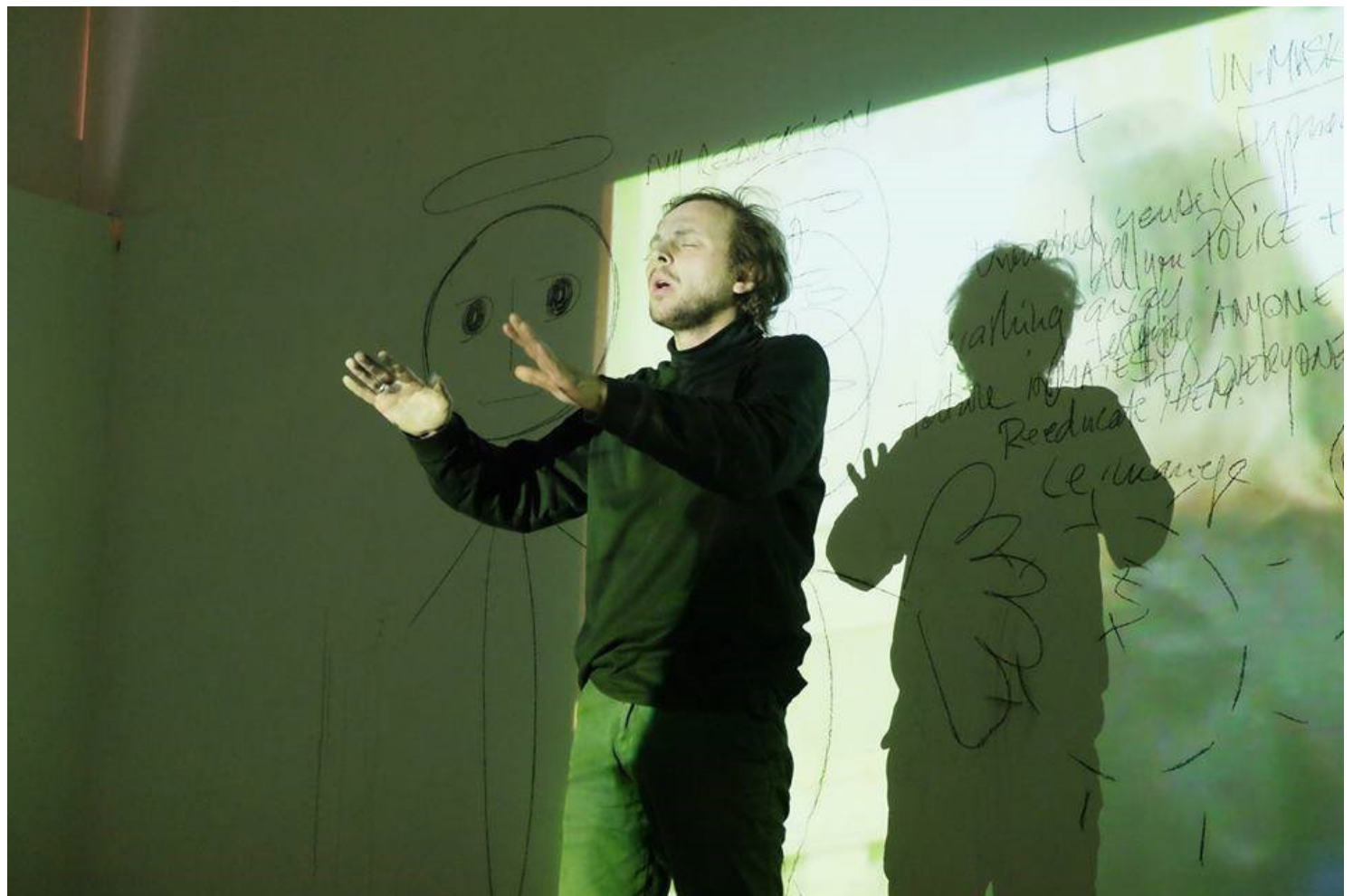

Fig. 2. The BANDIT living in the time lag between life and death. Copyright Nu Nu Theatre

the flow of trauma, allowing it to circulate-transindividually and across time-from the victims to the theatre-makers, from a medium-sized city in grim 1950s Romania to a flourishing, forward-looking city in the UK of 2016. The character of BANDIT came to represent the ghostly, multi-faceted, blurred, trans-individual voice of trauma belonging to no speaker in particular. That voice leaves individualities behind and enters into communion with millions of Romanian émigrés of our days. Such collaging technique allowed the belatedness of trauma to be clearly framed within the theatre piece: the character of BANDIT evokes "an unexpected or overwhelming violent event or events that are not fully grasped as they occur, but return later in repeated flashbacks, nightmares, and other repetitive phenomena." ${ }^{25}$ Performed on the British stage, BANDIT came to symbolise, with its kaleidoscopic flashbacks of horror and terror emerging from behind the (an) Iron Curtain, the ghost that is approaching, the ghost that is here to haunt, the trauma that flows from the East to the West. Similarly, this menacing perspective of the coming of the ghost is consecrated by an inherent exposure of the temporal, historical, and cultural lag between a terrifying prison of 1950s Romania and a theatre venue in 21 st century Britain.

What is, then, the ultimate purpose of bringing BANDIT-stories that happened sixty-five years ago in faraway Romania-to the 21st century British audiences? In early 2016, when the artists of $\mathrm{Nu} \mathrm{Nu}$ Theatre were devising and performing BANDIT, the Brexit campaign was in full swing. Covers of certain right-wing British magazines had been by then saturated with images of migrants and refugees pouring in, coming from their faraway troubled lands, tarred with plagues of suffering, war, and poverty. They were depicted as ghosts and zombies, transfigured by their suffering, menacingly approaching the shores of the West. The Romanian theatre-makers deemed it timely and useful to present BANDIT at a moment when suffering and trauma of others seemed to be perceived by many in the UK as a pollutant and an infestation coming from an alien world. As noted previously, the piece starts with a short animation which illustrates how Churchill and Stalin divided Europe with the infamous Percentages agreement. The leaders famously met at the Fourth Moscow Conference in 1944 and sealed the informal agreement, known since as the Percentages agreement, by 
which Europe was divided into spheres of influence. In his Memoirs of the Second World War, Churchill recollects in great detail the atmosphere in which this informal yet dreadful agreement was produced. Churchill said to Stalin:

Let us settle about our affairs in the Balkans. Your armies are in Rumania and Bulgaria. We have interests, missions, and agents there. Don't let us get at cross-purposes in small ways. So far as Britain and Russia are concerned, how would it do for you to have ninety per cent dominance in Rumania, for us to have ninety per cent in say Greece, and go about fifty-fifty about Yugoslavia? While this was being translated, I wrote out on a half-sheet of paper. I pushed this across to Stalin, who by then heard the translation. [...] Then took his blue pencil and made a large tick upon it and passed it back to us. ${ }^{26}$

With BANDIT, the makers deemed it appropriate to challenge right-wing propaganda against the ghosts coming from out there: an anti-EU, anti-immigration current of opinion often supported by a nostalgic, triumphant projection of the figure of Winston Churchill as the ultimate savior of the British nation and Europe in the Second World War. BANDIT allows the ghosts of those left behind the Iron Curtain (represented by the Romanian theatre-makers) to haunt audiences of Churchill's descendants with sufferings, tortures, and horrors of the past. In this symbolic gesture, the theatre-makers substitute themselves for the millions of other migrants and refugees: they, too, infested by other traumas, horrors, and sufferings, are coming to haunt these shores.

The short film invites the British audiences to symbolically join the makers (and, with them, all émigrés and refugees) in working through the still unprocessed trauma, asking: could it be that this haunting of today was caused, in part, by Churchill himself some sixty years ago? Should you, Churchill's descendants, not feel somehow compelled to participate in working through all this unprocessed trauma? This is discreetly suggested through lines as:
"Anton, why you say that we'll be released?" I asked. "That law student (another inmate) told me that either they give up or there's a war starting." "But Anton, how can you believe that? Why would they start a war? For me? For you? For the few here in this prison? Can't you see that we've been sold?" (Scene One) ${ }^{27}$

The theatre-makers use the carousel of horrors unleashed by BANDIT to haunt the British audiences and critique the insular tone of the right-wing media: in front of their eyes they create a view from the other (darker) side of the Iron Curtain, that of refugee camp gates and barbed wire. From a theatrical perspective, BANDIT represents the ghost of the trauma-bearing émigré freely engaging with the Western audiences, urging them to join this complicated process of working-through. Connoting an archetypal image of the other, the character of BANDIT grows to signify all the persecuted, traumatised, and tortured. He gives a voice to the pure, depersonalised, atemporal trauma and suffering of the ghostly other who hauntingly approaches the West. Therefore, the character of BANDIT grows (in his trans-individual construction) to represent all the exiles, the refugees, the rootless, the nomads: the ugly foreigners depicted in the right-wing press as invaders and carriers of disease and infestation. The name of all those who leave behind their countries and travel across the seas and continents, often together with their children and families, is borrowed from a ghost: BANDIT. To all these carriers of traumatic memories who so often end up locked again behind borders, barbed wires, or refugee camp gates, BANDIT symbolically offers a voice on the British stage. The performance becomes ritualised; the theatre-makers are instrumenting a return to a traumatic past which trickled perfidiously through the transgenerational communicating vessels of memory only to burst out, like a putrid sewage pipe, in front of the eyes of Churchill's descendants. Heirs of those who died a long time ago in the post-Iron Curtain prisons and brothers of today's refugees and emigrants, the makers of BANDIT realise-ceremonially-a link between the past and the future: they work through the time lag by making a trauma 
brought from a far away place haunt the British audiences. BANDIT can also be seen as an examination of a transgenerational and (by now) trans-historical and trans-national trauma that the theatre-makers have themselves never lived, but which was passed on to them through generations or across borders. In this sense, BANDIT functions like an affidavit of heirship in which the makers take possession of the trauma of their predecessors or fellow émigrés and refugees; they thereafter bring this reservoir of traumatic memory (of terror and violence) in front of the British audiences in an exercise of haunting.

From within their spectral status on the British stage, the makers of BANDIT ceremonially narrate of themselves and their fellows and ancestors and of the horrors of their (country's) past, as they dissect themselves with the scalpel of text and offer the unpleasant cuts to the intrigued, haunted hosts. BANDIT says: I'm here to haunt you! The role of the émigré artist consists, therefore, of bearing an unpleasant gift to the host audience. BANDIT is one such gift: the émigré artist, as Svetlana Boym observes, "is [taking] off his clothes like a reptile [shedding] his skin, attempting an unsuccessful mimicry of his renamed homeland."28 Philosopher Vilém Flusser suggests another possible insight into the émigrés haunting role, describing him/her as being:

unsettling to the native, [...] because he reveals the banality of the sacred to the native. He is hateful; he is ugly, because he exposes the beauty of home as nothing more than pretty kitsch. His immigration causes a polemical dialogue between the ugly stranger and the beautiful native. ${ }^{29}$

The BANDIT-makers argue that indeed, there is a growing need for a shared working-through of the traumatic past, and the émigrés unpleasant shedding of skins gives the British/Western audiences the opportunity to learn how it must have felt to be stuck on the other side of the Iron Curtain, barbed wire, fence, or gate. BANDIT is a call on the British hosts to rejoice in the opening of the communication vessels of traumatic memory: to welcome the ugly presents that the ghostly other brings, accepting, at the same time, the testing invitation to share into the other's peculiar patrimony of suffering and loss.

The uneasy role that the BANDIT-makers assume with their theatrical endeavour is that of foreign agents of demystification through the kitsch of molting. They undertake-like so many other émigrés (with their ugly customs, accents, diseases, or traumatic biographies) - the dirty job of opening a septic tank onto the embellished cosiness of home, calling on the British hosts to, as Flusser says, "open to the ugliness that confronts them and that could be transformed into beauty." ${ }^{30}$ The gruesome pestilence of incessant torture and violence in BANDIT is served to the audience as a reminder that, in Flusser's words, "more than anything, patriotism is a symptom of an aesthetic disease," and that each historical figure (Churchill's image was used in this particular instance, for obvious reasons) must necessarily be assigned their own dark shadow, their ghostly twin. ${ }^{31}$

To a nation whose cinema audiences have often given standing ovations to the film Darkest Hour (which reinforces Churchill's heroic image), BANDIT presents a not-so-appetising opening scene of a meeting between Stalin and Churchill that has partially helped unleash a string of unprecedented horrors behind the Iron Curtain. However, shaking off violence and terror and working through ugliness and trauma in BANDIT do not function as a form of retaliation or revenge. On the contrary, the theatremakers argue that Western Europe needs to encounter and indeed embrace Eastern Europe's ghostly suffering. The awkward, embarrassing arrangement of shards of terror is the (only) unpleasant gift that the Romanian theatre-makers (like some sort of poor relatives coming from the East) have to offer, after sixty years or so, to Churchill's descendants.

Beyond being a meditation on the ingrained precariousness of patriotism, BANDIT incites deeper, more fundamental questions, such as: How else can we (the Easterners) transgress our traumatic past if we do not let it haunt you and if you (the Westerners) do not agree to assume some of its burden? How else can we construct a truly united Europe if not by us coming here, in our millions, to haunt 
you? The gift of ugliness is a sacrificial offering that the makers of BANDIT bring to the hosts to, first of all, make some sense of the time lag that they have been captives of. The haunted one, as Flusser advises, should accept the haunting by the émigré as a most necessary gift. In other words, the haunted one must play the dangerous game in which he/she allows the émigré, the exiled to unload her traumatic spectrality:

So, it is indeed the master, the one who invites, the inviting host, who becomes the hostage-and who really has always been. And the guest, the invited hostage, becomes the one who invites the one who invites, the master of the host. The guest becomes the host's host. ${ }^{32}$

BANDIT is an invitation to the British hosts to allow the émigrés to haunt and taunt them with the ugliness and violence brought over from the other side of the Iron Curtain (whose positioning across Europe was influenced by Churchill).

\section{CONCLUSION}

The conclusion of the article is that the right-wing discourse is useful in one aspect: through the means of its fear-imbued depiction of the other (the other is always someone that instills fear-he is diseased, different, traumatised, of different colour, different religion, etc.), it draws our attention directly to the ghostliness of that other. The right-wing press and its anti-immigration discourse does us one major service: it provides a clearer, shorter (the fear of the other acts as a contrast agent in medical practice) route to Žižek's real, which "possesses" all these incoming people.

This is the fear that any anti-immigrant discourse reveals: the impossibility to assign structure and meaning to this irrepresentable $\mathrm{X}$ that the émigré brings along with him/her, the subsequent struggle to settle its incontrollable ghostly nature, which is a symptom both of past trauma and of entrapment in a time lag. This is what really stirs fear, making the immigrant an utterly dangerous presence: such irrepresentable $\mathrm{X}$ is here to stay, to haunt the host, and to change his/her home. The role of the émigré artist becomes crucial in such context. In their

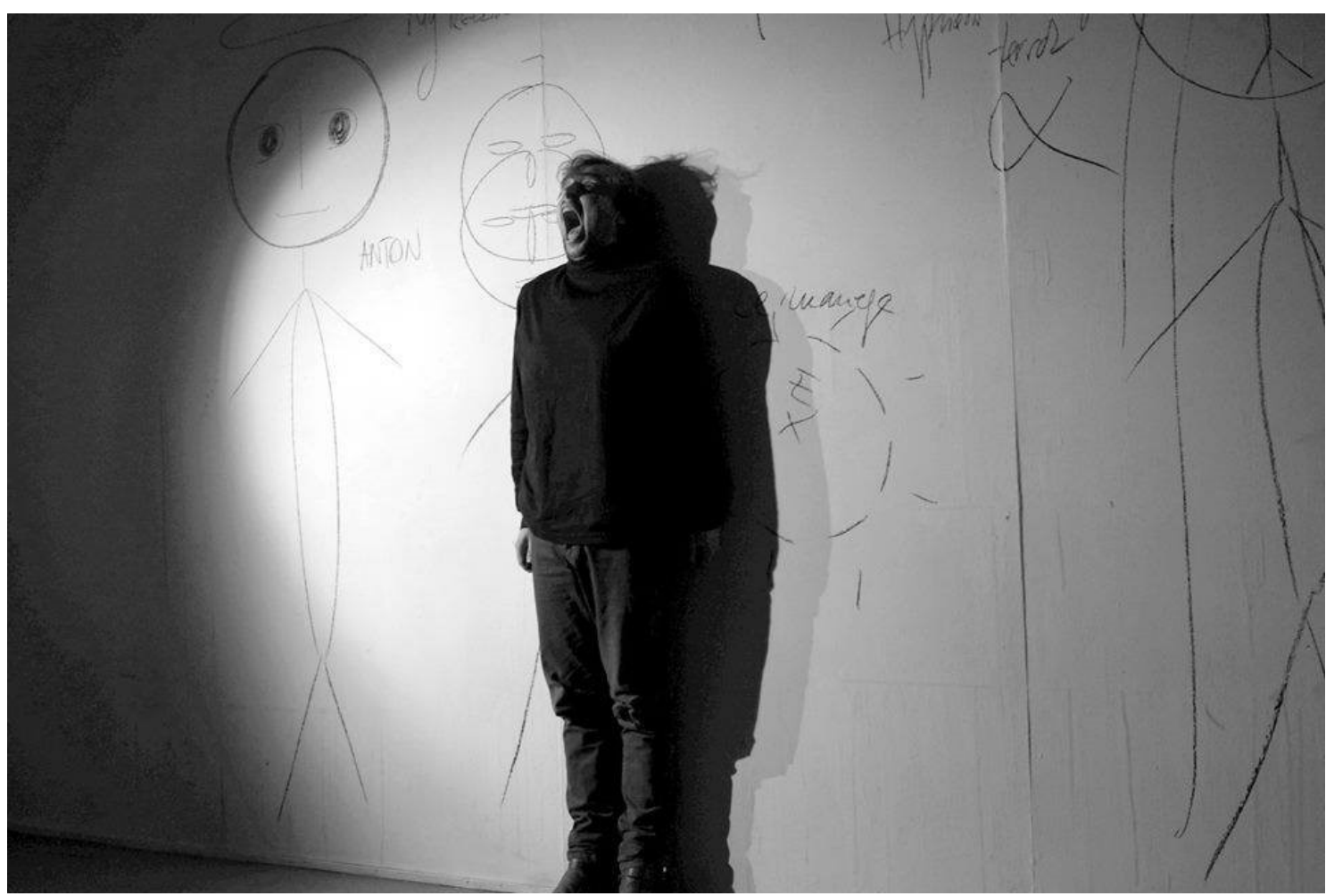


work, such artists should advocate that the Western audiences do not shy away from but let themselves be haunted and transformed, infested by the spectrality of the other's real. The role that the makers of BANDIT assign themselves in their new life in the UK is to become theatrical agents of disruption that challenge the cosy patriotism of the audiences. They bring to the audiences an uglier face of Churchill, haunting his otherwise heroic image. The émigré artists are not in the UK to make nice: they remind the audience that suffering, trauma, and ugliness are not just some undesired diseases imported from troubled lands. On the contrary, they constitute unusual, uncomfortable, yet valid and indispensable contributions to the broader discourse of acceptance, tolerance, and, most of all, reconciliation. This other version of real (a ghostly one) that an émigré artist always invokes in his/her work is the ingredient without which any society or community would miss its completeness: without it, the host would become like a person missing their shadow.

\section{References}

Andreescu, Gabriel. Existenta prin cultura. Represiune, colaborationism si rezistenta intelectuala sub regimul communist. Iași: Editura POLIROM, 2015.

Bantaș, Andrei. To the star. Accessed April 13, 2019. http:// luceafarul.com/Pages/sbsuntothestarsbantas.html

Blandiana, Ana. Istoria ca viitor. Accessed April 13, 2019.

https://s3-eu-central-1.amazonaws.com/pressone/ wp-content/uploads/2016/03/24175425/DiscursulAnei-Blandiana-de-acceptare-a-DHC-UBB-Cluj.pdf

Bloch, Ernst. Heritage of Our Times. USA: California University Press, 1991.

Bloch, Ernst, and Mark Ritter. "Non-Synchronism and the Obligation to Its Dialectics." New German Critique, 11 (Spring 1977): 31.

Boia, Lucian. La mythologie scientifique du communisme. Paris: Les Belles Lettres, 2000.

Boym, Svetlana. The Future of Nostalgia. New York: Basic Books, 2001.

Caruth, Cathy. Trauma: Explorations in Memory. Baltimore: Johns Hopkins University Press, 1995.

Caruth, Cathy. Unclaimed Experience: Trauma, Narrative, and History. Baltimore: Johns Hopkins University Press, 1996.

Churchill, Winston. Memoirs of the Second World War. Boston: Houghton Mifflin, 1991.

Defourmantelle, Anne. Of Hospitality: Anne Defourmantelle invites Jacques Derrida to respond. California: Stanford University Press, 2000.
Derrida, Jacques, and Bernard Stiegler. "Spectrographies." In The Spectralities Reader: Ghosts and Haunting in Contemporary Cultural Theory, edited by Maria del Pilar Blanco and Ester Peeren. London: Bloomsbury, 2013, 37-53.

Durst, David. "Ernst Bloch's Theory of Nonsimultaneity." The Germanic Review: Literature, Culture, Theory, Volume 77, Issue 3, 2002, 171-194.

Flusser, Vilém. Writings. Edited by Andreas Stohl. Minneapolis: University of Minnesota Press, 2002.

Freud, Sigmund. Beyond the Pleasure Principle. New York: Liveright Publishing Corporation, 1961.

Jürs-Munby, Karen. "'Did you mean post-traumatic theatre?': The vicissitudes of traumatic memory in contemporary postdramatic performances." Performance Paradigm. Volume 5, Issue 2, October 2009, 201-223.

LaCapra, Dominick. History in Transit: Experience, Identity, Critical Theory. Ithaca, New York: Cornell University, 2004.

Malkin, Jeanette. Memory: Theatre and Postmodern Drama. USA: University of Michigan Press, 1999.

Nedelcovici, Bujor. Un tigru de hartie. Eu, Nica si Securitatea. Bucharest: Allfa, 2003.

$\mathrm{Nu} \mathrm{Nu}$ Theatre. BANDIT. Accessed September 28, 2019. https://www.youtube.com/watch?v=Po_60GDoRwc

Rand, Nicholas T. "Editor's Note." In The Shell and the Kernel: Renewals of Psychoanalysis, edited by Nicholas Abraham and Maria Torok. Chicago: University of Chicago Press, 1994.

Reed-Danahay, Deborah, ed. Auto/Ethnography: Rewriting the Self and the Social. New York, Oxford: Berg, 1997.

Rusan, Romulus, ed. Anale Sighet 10. Anii 1973-1989: Cronica unui sfarsit de system. Bucharest: Fundatia Academia Civica, 2003.

United Nations. "International Migration Report 2015: Highlights.” Accessed April 13, 2019. http:// www.un.org/en/development/desa/population/ migration/publications/migrationreport/docs/ MigrationReport2015_Highlights.pdf

Weinstock, Jeffrey Andrew. "Introduction: The Spectral Turn." In Spectral America: Phantoms and the National Imagination. Madison: University of Wisconsin Press, 2004.

Žižek, Slavoj. The Sublime Object of Ideology. New York: Verso, 1989.

Žižek, Slavoj. Mapping the Ideology. New York: Verso, 1994.

\section{Notes}

1 Andrei Bantaş, To the star, accessed April 13, 2019, http://luceafarul.com/Pages/sbsuntothestarsbantas.html

2 Ernst Bloch, Heritage of Our Times (USA: California University Press, 1991), 30.

3 Ernst Bloch, Mark Ritter, "Non-Synchronism and the Obligation to Its Dialectics," New German Critique 11 (Spring 1977): 31.

4 Ana Blandiana, Istoria ca viitor, accessed April 13, 2019, https://s3-eu-central-1.amazonaws.com/pressone/ wp-content/uploads/2016/03/24175425/Discursul-AneiBlandiana-de-acceptare-a-DHC-UBB-Cluj.pdf 
5 David Durst, "Ernst Bloch's Theory of Nonsimultaneity," The Germanic Review: Literature, Culture, Theory, Volume 77, Issue 3 (2002): 171.

6 Ibid., 178.

7 Gabriel Andreescu, Existenta prin cultura. Represiune, colaborationism si rezistenta intelectuala sub regimul communist (Iași: Editura POLIROM, 2015), 323.

8 Ibid., 314.

9 Anale Sighet 10. Anii 1973-1989: Cronica unui sfarsit de system, ed. Romulus Rusan (Bucharest: Fundatia Academia Civica, 2003), 41.

10 Bujor Nedelcovici, Un tigru de hartie. Eu, Nica si Securitatea (Bucharest: Allfa, 2003), 21.

11 Jeffrey Andrew Weinstock, "Introduction: The Spectral Turn" in Spectral America: Phantoms and the National Imagination (Madison: University of Wisconsin Press, 2004), 6

12 Slavoj Žižek, The Sublime Object of Ideology (New York: Verso, 1989), 55.

13 Jacques Derrida and Bernard Stiegler, "Spectographies" in The Spectralities Reader: Ghosts and Haunting in Contemporary Cultural Theory, ed. Maria del Pilar Blanco and Ester Peeren (London: Bloomsbury, 2013), 38.

14 Žižek, The Sublime Object of Ideology, 75.

15 Slavoj Žižek, Mapping the Ideology (US, New York: Verso, 1994), 21.

16 Lucian Boia, La mythologie scientifique du communisme (Paris: Les Belles Lettres, 2000), 6.

17 United Nations, "International Migration Report 2015: Highlights," accessed April 13, 2019 http://www. un.org/en/development/desa/population/migration/publications/migrationreport/docs/MigrationReport2015_ Highlights.pdf, 19.
18 Nicholas T. Rand, "Editor's Note" in The Shell and the Kernel: Renewals of Psychoanalysis, ed. Nicholas Abraham and Maria Torok (Chicago: University of Chicago Press, 1994), 168.

19 Cathy Caruth, Trauma: Explorations in Memory (Baltimore: Johns Hopkins University Press, 1995), 4.

20 Karen Jürs-Munby, "Did you mean post-traumatic theatre?': The vicissitudes of traumatic memory in contemporary postdramatic performances," Performance Paradigm, 5.2 (October 2009): 2.

21 Jeanette Malkin, Memory: Theatre and Postmodern Drama (USA: University of Michigan Press, 1999), 31-32.

22 Sigmund Freud, Beyond the Pleasure Principle (New York: Liveright Publishing Corporation, 1961), 10.

23 Dominick LaCapra, History in Transit: Experience, Identity, Critical Theory (Ithaca, New York: Cornell University, 2004), 143.

24 Blandiana.

25 Cathy Caruth, Unclaimed Experience: Trauma, Narrative, and History (Baltimore: Johns Hopkins University Press, 1996), 91.

26 Winston Churchill, Memoirs of the Second World War (Boston: Houghton Mifflin, 1991), 226.

$27 \mathrm{Nu} \mathrm{Nu}$ Theatre, BANDIT, accessed September 28, 2019, https://www.youtube.com/watch?v=Po_60GDoRwc 28 Svetlana Boym, The Future of Nostalgia (New York: Basic Books, 2001), 271.

29 Vilém Flusser, Writings, ed. Andreas Stohl (Minneapolis: University of Minnesota Press, 2002), 95.

30 Ibid., 101.

31 Ibid.

32 Anne Defourmantelle, Of Hospitality: Anne Defourmantelle invites Jacques Derrida to respond (California: Stanford University Press, 2000), 125.

\section{„BANDIT“: DABAR JUMS VAIDENSIUOS! IR KODĖL AŠ TAPAU ÉMIGRÉ TEATRO KÜRĖJU}

\section{Santrauka}

Šiame straipsnyje naudojamas Ernsto Blocho atsiliekančio laiko (time lag) konceptas ir iš Jacqueso Derridos perimtos šmèklos ir vaidenimosi formuluotès. Straipsnyje taip pat pasitelkiamos Svetlanos Boym ir Vilémo Flusserio émigré (iš pranc. k. - tas, kuris emigravo) vizijos bei Dominicko LaCapros ir Slavojaus Žižeko interpretacijos apie traumą. Spektaklio analizė atliekama ịveiksminant ir Karen Jürs-Munby, Cathy Caruth požiūrius ị traumą ir jos reprezentacijas teatro scenoje.

Šis kritinis diskursas panaudojamas konkrečiame BANDIT analizès kontekste: teatro projektui, ịkurtam Jungtinëje Karalysteje dviejų teatro kūrejų, emigravusių iš Rumunijos. Pagrindiniu analizès aspektu tampa ryšys tarp aliuzijų ì traumą, būdingų BANDIT teatro projektui, ir šio teatro projekto kūrejų pasirinktos egzilio patirties Jungtinèje Karalysteje. 
- Šiuo straipsniu siekiama atsakyti $\mathfrak{i}$ tokius klausimus kaip: kas mus, BANDIT teatro projekto kūrejjus, paskatino palikti gimtąją šalį; koks yra mūsų (naujas) (kaip menininkų) vaidmuo emigracijos šalyje? Tokio pobūdžio diskusija atliekama platesniame didžiulès Rumunijos piliečių emigracijos ị Vakarų Europą bangos (po geležinès uždangos griūties) kontekste. Straipsnyje taip pat kritikuojamas problematiškas šiuolaikinės Rumunijos visuomenès santykis su komunistine praeitimi bei negebejjimu ar / ir nenoru spręsti represuotus / traumatinius kolektyvinius prisiminimus.

BANDIT performanso kaip užsitęsusios traumos analizè taip pat kuria aliuzijas $\mathfrak{i}$ istorines Stalino ir Churchillio „Svarstyklių“ dalybas (neformalų susitarimą dèl ịtakos sferų pasidalijimo Europoje po Antrojo pasaulinio karo). Pažymètina, jog šiame straipsnyje Geležinè uždanga tampa Rytų Europos traumatinès atminties epicentru, o diskusija apie BANDIT, žyminti nuorodas ị komunistų nusikaltimus, vykdytus prieš politinius kalinius Rumunijos kalèjimuose 1951-1952 metais, taip pat tampa paralele toksiškai Europos Sajungos referendumo kampanijai, ịvykusiai 2016-aisiais Jungtinèje Karalystèje.

Aktyvuojant Derridos požiūri, straipsnyje aiškinama, kaip Rumunijos émigré menininkai (kaip Rumunijos / Rytų Europos emigrantų pavyzdys apskritai), reprezentuojantys save it šmẻklas, persekiojančias perimtą kultūrą, îveiksmina meninę išeiviją, tampančią neišspręstos traumatinès atminties platforma.

Reikšminiai žodžiai: atsiliekantis laikas, émigré, trauma, komunizmas, šmèkla, vaidenimasis, Churchillis.

\section{Bogdan Mihai FLOREA}

University of Bristol, Bristol, United Kingdom

E-mail: bf0028@bristol.ac.uk 